\title{
Students in the (Ancient) Streets, or Agent(s) Provocateur? The Liberal Arts Schools of Athens and the Hostage Crisis of 88
}

\begin{abstract}
By David P. Wick*
One of the odd angles in the story of Athens' second greatest 'hostage crisis' moment is the student protest or 'Athenian student independence' movement, often part of how the "siege of Athens" in 88 of the old era gets its narrative. This qualifies as 'second' greatest if one interprets the greatest as the city's takeover and destruction by Xerxes in 480 of that same era. In this second crisis the city's 'liberal arts' schools - they were by the late Roman Republic's era one of the drivers of the city's economy - are often seen spurring it to resist Roman imperialism, even to the extent of taking children of town business families hostage on the Acropolis and inviting a foreign power (Mithridates) to invade and save the city from Rome. All this happens under the twin shadows of Rome's civil war against Sulla, and the Anatolian war of conquest launched by Mithridates -- and in an Athens that had become a sort of flame-keeping educational and artistic symbol for the new European/Mediterranean culture clustering itself around Italy in the west, Athens itself leaning toward Europe but forced into a disastrous bit of political theater, in which Athenian townsfolk (those unable to flee) were used, and starved, as symbols for the agents of either an Anatolian coup, or a coup by students who alone valued the ancient independence and brilliance of the city's 'Greekness.' This study looks at the Athenian part in the Crisis of 88, from the political troubles in the decades preceding which made the city vulnerable, through the various internal coups in the crisis year that left Athens a city divided between refugees and captives, to the ultimate dilemma: an armed external insurrection holding the Acropolis and attempting to bar the gates, and a Roman renegade outside the walls desperate for any sort of improvisational victory, without regard for the fragile treasures of culture trapped within its walls. Among the threads untangled to pursue the story are brief looks at the Athenian-educated 'student rebel' or Anatolian agent Athenion, and of the military adventurer Aristion of Rhodes, and the local public support they raised against Rome (some of it certainly seemed to come from 'students in the streets). Also worth notice are careers of the Athenian financial-political families of Medeius (the Piraean) and Sarapion of Melite, who play either as pro-Roman or independent 'power-gamers' who may have helped make the hostage crisis possible. Much of the evidence for these episodes is dependent (via Plutarch) on fragments of Poseidonius, with help from surviving inscriptions, but the study attempts to find a reasonable, respectful way of dealing with writers who, whatever their stylistic eccentricities, were quite a bit closer to the events and to the historical heritage of these events than we are.
\end{abstract}

\section{Students in the Streets, or Agents Provacateur: An Ancient 'Hostage Crisis' case study in Athenian History}

"Poor leaders motivate those following them with false promises of promotions, success, and a great tomorrow but rarely deliver on those promises. Leaders who do this can be manipulative and often hold the goals and aspirations of their followers hostage in order to get them to comply."

Lewis Howes

"Professor, Gordon College, USA. 
"...the state was like a sick body which had lately taken physic, whose humours are not yet well settled, and weakened so much by purging, that nothing was left but melancholy."

R. Dallington, 1596, in a survey of Tuscany ${ }^{\mathrm{a} 1}$

It may seem a little odd that in our era, an era one could almost dub 'the age of the hostage crisis,' Athens -- which weathered perhaps the landmark hostage crisis of all ancient history in the terrible year 88 of the old era -- should not be better known for it. The story is dramatic enough, though possibly not dramatic in the way modern readers might wish; it is a history of the ancient city caught between independence of a sort (which is the line we most quickly find attractive) and the dilemma over whether it should be a "European" or an "Asian" city. This latter is a very modern and Greek issue, easy for politicians to make sweeping, inclusive generalizations about, but awkward to live with. This tale of one of ancient Athens' very modern moments is then less comfortable because it has a strong contemporary resonance. Might it be worth reviving for that very reason?

Epic Athenian historians like Ferguson and Ferarry seem to have desired the lines of grand tragedy for this story (Athens finding in itself some great realization of, and then defiance of, the tyranny of Rome), but if the events of the 80 's before the Christian and imperial era are to carry that flavor, we ought to find the early signs of them in the decades beforehand. Athens ought, under such scenarios, to grow either more imperialistic or more nationalistic in the prosperity of its last authoritative years as a power in the southern Aegean. More imperialism might have set it against Rome (and with Mithridates of Pontus) or at least influenced it toward using the theme of Greek freedom at last. The usage would at least have been no more dishonest than the messages displayed in public by Athens or a dozen other authentic Greek powers in previous centuries.

The central story, whatever its spin, is that of Athens captured in Mithridates' interest in the early 80 's, and then besieged by the Roman renegade Sulla before his march on Italy, Athens battered and nearly starved, its back to the walls of the Acropolis as barbarians tear up the trees of the Academy grove to make siege engines, the Athenian living, as Sulla put it, spared "for the sake of her dead." 1 More Greek nationalism would be the best thing for such an historian to find here. Athens could finally grow to fill, in the disaster that concludes this story, the wistful image of it painted, proclaimed, and used even by the Romans, whether scholars, tourists, or agents of republican power. That this idea is in fact

a1. Quoted by R. Burton, Anatomy of Melancholy, "Democritus to the Reader".

1. "[The Athenians] expected from Sulla neither generosity nor ordinary humanity. Finally, however, partly because of the exiles ... who threw themselves at his feet and begged him to have mercy, partly because of the Roman senators with the army who also interceded for the city, Sulla, who was by now sated with vengeance, made a few remarks in praise of the ancient Athenians and then announced, 'I forgive a few for the sake of the many, and the living for the sake of the dead."' Plutarch, Sulla, 14 
very nearly what the sophistic dictator Athenion and Mithridates' agent Aristion proclaimed the city was doing all but clinches the argument; except that both failed hold any following among Athenian citizens. Aristion had actually to kill as many of the Athenians as his opponent Sulla simply to keep them within the walls; hardly the leader of a "democratic" revolt.

It might also help if we could notice an undercurrent of democratic resistance against Rome. Ferguson, and a great many Athenian apologists after him, have claimed it was there. They simply seem unable to find an example of the demos revolting against the Roman world. The only revolt of any kind - the coup of the philosophe Athenion in 88 - revolved too thoroughly around a small, educated, and internationalist elite, and was too short-lived to be called a "movement." It has in any case come under the scrutiny of Professor Badian in recent years, and has escaped with very little of its "democratic" nature intact. ${ }^{2}$

\section{The (Discoverable) Setting - Athens before the Crisis}

We do know (and the evidence is sparse for Athens in this period) that Athens experienced a run of fairly quiet years in the last decades of the second century B.C. It kept its ties with Delphi, settled much of the business and banking expertise learned on Delos into its own marketplaces, and allowed an increasingly internationalist crowd of young Romans (and Asians) into its schools and ephebeia. It had for a long time educated the serious students and the royal children of the Hellenistic east. It now instructed whole generations of young aristocracy from the east, and especially from the west. They arrived, they complained about the oddity of "graecia capta," they studied, they contributed to the library, they drank, they visited the old sites, and they went home - unable to explain the ways in which the city had changed them, but changed nonetheless.

Athens continued most importantly to be Athens in the sense useful to its Roman rulers: an "outward and visible sign" that Greekness could settle comfortably into the world of Rome. If Athens had not succeeded so well in becoming Roman Athens before the rise of Mithridates, the Pontic king would not have needed to abuse it so badly. Its docks were good, but hardly essential to a Black Sea king relying on the vagabond fleets of pirates. The eloquence of its existence as a definition of what it meant to be Greek was irreplaceable.

In fact Athens, after hitching its civic fortunes to the Roman Republic both as a protector and as a source of business connections, had done well by "going European. The lessons it learned operating Delos - a willingness to improvise and apply business expertise where some hot and crafty shouting in the Agora might

2. Badian, "Rome, Athens, and Mithridates," in American Journal of Ancient History, vol. 1 (1976): 502, 505, 512. 
have sufficed - were once mistaken by Ferguson as the arrival of oligarchy. ${ }^{3}$ In the two decades that marked the end of the second and the beginning of the first centuries B.C., a loose succession of Athenian aristocrats and former Delian officials revamped the infrastructure of Athenian commerce so well that it set (almost literally) the economic standards of Greece. Details of this I have discussed elsewhere, but Athens added enough economic prestige to its political auctoritas in some cases to merit mention here.

So, at about the turn of the century Diodorus of Halae made a revision of the Athenian commercial weights and measures sophisticated enough to become a model for other Greeks. ${ }^{4}$ Athens also set clear and reliable formulae for the conversion of various Greek measures into the systems used in Phoenicia and Rome. When the Amphictyonic league at Delphi announced about 95 B.C. that the tetradrachm in all its territory must thereafter conform to the Athenian one, it seems to have recognized that Athens had followed an irreversible shift in the business of the Mediterranean as well as its politics. It had been one of the marks of Greek independence in the old era that each small polis measured money, crops, or value of any kind in its own way; measurements like coinages or religious calendars or systems of dating had been part of the private language of freedom. The banks of Athens were now prepared to speak the commercial language of the wider world - especially of Rome - on a regular basis. The economic tides had shifted, for Roman reasons, in an Athenian direction.

It will not do, consequently, to explain an Athenian pull toward Mithridates in terms of nationalism, either popular or oligarchical. The impulses both of power and politics that ended the Athenian "Indian summer" ran not eastward from Attica but westward from Pontus.

\section{'Oligarchic Creep' - The Confused Democracy of the Early $1^{\text {st }}$ Century}

The attempt by Ferguson and Mossé to discover an "oligarchic" revolution behind this shift in the center of Athenian political gravity has largely evaporated in recent years, though it has left in its wake a trail of clues about domination by wealthy individuals. Ernst Badian - never gentle with the proponents of "political parties" in the ancient world - pointed out that while many of the new leaders in the Athenian government of expertise might have been riche, most of them were not nouveaux. Sarapion of Melite appears to have been a political outsider. ${ }^{5}$

3. W.S. Ferguson, Hellenistic Athens: an Historical Essay (London, 1911), 421 ff. Badian, ibid., 502-505. See above, note 1 .

4. Inscriptiones Graecae (vol. II), 476. Ferguson, 427-430.

5. Badian, "Rome, Athens, and Mithridates," 503. 
Medeius the Piraean was a pedigreed member of the priestly aristocracy. ${ }^{6}$ Between them, they dominated the Athenian government of the 90 's by a combination of sweeping appointments and vast, competitive donations.

Medeius was, for instance, archon in 101, hoplite general in 99, and probably in 98 found himself commissioner of the civic bank on Delos, Athenian overseer of Delos itself, and sponsor of both the Panathenaea and the Delian Games. ${ }^{7}$ All Athenian offices of any consequence involved a financial assessment (the equivalent of an additional liturgy, which one might recoup from the economic "opportunities" of the office itself). Every one of these offices ranked in the most expensive class: those political at 200 drachmas each, and the two "festival" offices at 250 .

In that same or following year Sarapion held the hoplite generalship for at least the second time, and gave 950 drachmas-worth of games (two on Delos, two in Athens). ${ }^{8} \mathrm{He}$ will have also paid for the generalship. His successor Pyrrhus of Lamptrae had been Herald of the Areopagus in 98, and installed his brother Byttacus as head of the civic bank.

Badian rightly sees some kind of war of individual largesse here, rather than Ferguson's coup by an "oligarchic party", but there are perhaps more kinds of oligarchy in the world than Badian's critique allows. The Roman optimate and populares leaders in the later Republic may nearly all have been patrician, but they attempted coups against one another (and the rest of the Roman constitution) nevertheless. Whatever Badian may argue about the details of Athenian government in the years before the Mithridatic war, the evidence he has brought to bear does indeed suggest some kind of "creeping coup," albeit one in which different members of the same class (all claiming to exercise a new kind of business expertise) were competing with one another for lasting power. The mechanism seems to have been one of holding political and fiscal appointments as much as possible at the same time, and then using some of the proceeds of this synergy to indulge in civic patronage on a grand scale.

We do not have evidence for the whole of the decade before the war (Medeius may have been eponymous archon four times, and Sarapion hoplite general as many as three - each in connection with other offices), ${ }^{9}$ but the crisis began to show itself in about the year 91. Medeius held his second archonship in that year, and kept the post for the two following years. His two moneyers held

6. P. MacKendrick, "The Athenian Aristocracy 399-31 B.C.," Martin Lectures, vol. xiii (1969), $58 \mathrm{f}$.

7. Badian, "Rome, Athens, and Mithridates," 503, n. 9.

8. S. V. Tracy, Inscriptiones Graecae $I^{2} 2336$ : Contributors of First Fruits for the Pythaï, (Meisenheim am Glan : A. Hain, 1982), 134-135, 173.

9. Ferguson, 436; Badian, "Rome, Athens, and Mithridates," 504. 
on to their place in charge of the mint. ${ }^{10} \mathrm{He}$ seems to have found some means of seizing the government and keeping it. Poseidonius (or an extract preserved in Athenaeus) ${ }^{11}$ suggests that money or transferrable debts were changing hands somewhere in the Athenian upper classes - whether used by Medeius to keep power, or whether Medeius kept power to avoid paying such debts is no longer clear. Public opposition arose; festivals were suspended; and the matter referred to the Roman Senate. ${ }^{12}$ When the Senate, embroiled now by the Social War in Italy and worried about military rumblings in Mithridates' Pontus asked Medeius to preserve the status quo a while (its typical manner when playing for time), he continued rule Athens after his last archonship expired..$^{13}$

Athens was now in a state of anarchy, according to the strictest Greek definition of that word. No legitimate archon headed the city. At some point in late 89 or early 88 Medeius appears either to have died or been driven from office. During the opening holocaust and "blitzkrieg" stages of Mithridates' war in Asia Minor (in which he took all of Asia Minor, captured several provincial governors, and killed some 80,000 private Roman citizens, most of them likely Hellenistic Asian or Greek) Athens appears to have sent, or allowed, a diplomatic mission to "feel out" the intentions of Mithridates himself. This was led by Athenion, a young student of the Peripatetics - if Ferrary has disentangled him correctly from the web of the first century Lyceum - whose father had studied with distinction under Diodorus of Tyre. ${ }^{14}$

\section{Protégé of the Lyceum - or Pontic 'Provocateur?'}

Poseidonius describes him as "elected by the Athenians," and describes letters "to the Athenians" sent by him from Pontus during $88 .{ }^{15}$ It would be helpful if we had some account other than Poseidonius' (who though an extremely intelligent source betrays a Rhodian prejudice against Athens and a Stoic prejudice against Peripatetics). In any case his mission was thus either an

10. Three series of coinages were issued in these years by Harmoxenus (and Xenocles), one issue showing a statue of Roma; Harmoxenus would re-appear as mint magistrate in 86. Cf. Ferguson, 440, and n. 2.

11. Athenaeus v, 212a.

12. Inscriptiones Graecae (vol. II), 5.477d probably shows public activity continuing at least to the archonship of Demochares (94/93 B.C.).

13. Athenaeus v, 213c f., is the only evidence (if the reconstructed speech of Athenion is evidence) that this was popularly believed to be the result of Roman interference.

14. Ferrary, Jean-Louie, Philhellénisme et Impérialisme: Aspects Idéologiques de la Conquête Romaine du Monde Hellénistique, de la Seconde Guerre de Macédoine à la Guerre Contre Mithridate (Rome, 1988), 467, 468.

15. Athenaeus v, 212a (where the phrasing is exceedingly general, and connects Athenion to no "party"). 
Athenian enterprise or one prompted by his school; Ferguson's embassy from "the democratic party" in town is an alternative guess unsupported by evidence.

His return to Athens is even harder to date, or to explain thoroughly. Badian argues that Mithridates' "Asian Vespers" had not occurred yet, since they are not mentioned, but on rather slim grounds. ${ }^{16}$ Since Athenion returned arguing a very sharp case for Athens to declare itself either neutral or to "Mithridatize" (it is difficult to tell which), and fired with an urge to take over the government himself, he would very likely have suppressed, denied or propagandized the slaughter of the Roman civilians. Athens was now full of Romans, and of Greeks whose livelihoods - even whose identity and image of themselves - were intimately bound to Rome and the Roman elements in the city. All that we are certain of is that somewhere in mid- 88 he returned richly dressed, well supplied with money, and his head filled with distinct, new ideas. It would be nice to know what the ideas really were. Poseidonius notes with delighted disdain the details of his new wardrobe (adding that he was put up in the house of a Delian tycoon named Dies) ${ }^{17}$ but compresses or invents all Athenion's notions into a set speech.

The young student, addressing an assembly apparently near his house in the Kerameikos rather than at the assembly site on the Pnyx, spun as Poseidonius tells it a golden fantasy of speech in which Mithridates strutted like an opulent and invincible monarch of all the ancient Persian domains. Roman governors cowered in chains behind his immense Scythian guards. The world, including the Carthaginians, ${ }^{18}$ begged to join him in destroying Rome. He then accused the Athenians of stalling the onrush of history without ever, precisely, telling them to oppose Rome themselves. Instead, he attacked the anarchia caused by the regime of Medeius:

Let us not stand by inactive while the temples are shut, the gymnasia foul through disuse, the theater without the ecclesia, the jury-courts silent, and the Pnyx taken away from the people ... Let us not stand by inactive, men of Athens, whilst the sacred cry Iacchos is silenced, and the hallowed sanctuary of Castor and Pollux is closed, and the conference halls of the philosophers are voiceless." 19

Athenion had in fact attacked an Athens deprived of its traditional public activity, perhaps because of pressure from Rome (as Badian suggests but does not argue), or because various rival factions competitive with Medeius had the city in a gridlock after that politician's disappearance. The outcome is more important.

16. Badian, "Rome, Athens, and Mithridates," 509 f. Cf. Appian, Mithridatic Wars xxivxxvii, especially the timing of the capture of Oppius (xx, 79) and Aquillius (xxi, 80) compared to that of the "Asian Vespers" themselves.

17. Athenaeus $v, 212 b$.

18. Idem.

19. Idem. The translation is Ferguson's, 443. 
Athenion was immediately voted hoplite general and named a "cabinet" of friends who were also elected. At no point in the story does Poseidonius suggest he was prominent among the city's Peripatetic scholars, or that he had ever had political experience; we have instead merely the intellectual tastes and speaking style of a successful demagogue. ${ }^{20}$ His colleagues in the new government are known from an inscription; ${ }^{21}$ all from well-placed families, some priestly, and several distinguished by important appointments during the previous decade of extravagant political competition. ${ }^{22}$ They cannot have arrived at this suddenly exalted status by accident: Badian notes quite reasonably that this is not an antiRoman popular mob; he might also have asked if this clique might not be identical to the putative "Athenians" who elected Athenion, and to whom he wrote. The only Athenion we can reconstruct from our sources is a fiery young second-generation Peripatetic student (perhaps describable by comparison with the skeptics of the Academy and the social philosophers of the Stoa as a "political scientist") with strong connections to one faction among the Athenion elite, and a fiery gift for rhetoric. The connection to Dies may suggest that the faction had its own echo (and perhaps an echo of its enemies) on Delos as well.

\section{The Momentum of Disaster - Insider 'Revolt' to Outsider 'Hostage Crisis'}

Events now made Athenion's decision for him. A rapidly increasing trickle of Athenians began to flee the city, asking for Roman protection. By the time Athenion managed to guard the gates this had become a general exodus, which he could punish only by confiscating the property of those now absent. ${ }^{23}$ Poseidonius does not, interestingly, identify these refugees as Romans, but their direction of flight shaded the diplomatic stance of the Athenian regime by implication.

Delos also revolted in favor of Rome (Mithridates had nearby pressed an unsuccessful siege of Rhodes). ${ }^{24}$ By doing so it forced Athenion, whose new regime needed the island's profits, to act as the apparent lieutenant of Pontus. The faction chose as its admiral to recover Delos the adventurer, bookdealer, and sometime forger Apellicon of Teos who took what skeleton fleet Athens could

20. Athenaeus v, 212, 3e

21. Inscriptiones Graecae (vol. II2), 1714. Cf. S. Dow, "The Lists of Athenian Archontes." Hesperia, vol. iii, no. 2, (1934), 444 ff. Badian, "Rome, Athens, and Mithridates," 510.

22. Badian, "Rome, Athens, and Mithridates," 511, n. 29.

23. This account that of Poseidonius, via Athenaeus, and so the emphasis on Athenian resistance Athenion and Mithridates ought to appear more remarkable than it has especially to those who use the previous passages as evidence that Athens was spoiling for a chance to rise against Rome. Cf. Ferguson, 445-446.

24. Appian, Mithridatic Wars v, 24-27. 
launch with him into the Aegean, but failed to defeat the rebels. ${ }^{25}$ On his return Athenion vanishes from power, and from our sources.

Mithridates, having failed at Rhodes and needing some sort of diversion to facilitate his planned northward sweep into the Aegean world, now decided to play a card of his own at Athens as much like the near-success of Athenion as he could improvise. This we can deduce from two clues. Athenion, first of all, could mention a planned northward campaign to his audience during his speech in 88 (without any mention of Mithridatic interest in Athens). ${ }^{26}$ Secondly, a creature named Aristion appeared in Athens shortly after the Delian expedition, carrying assurances and some armed force from the king himself, and rapidly seizing the government by force. ${ }^{27}$

Appian identifies Aristion as an "Epicurean" of some sort, indicating presumably that he so identified himself in Athens. He does not imply that the man was a philosopher or teacher, or that he belonged to the Athenian "Garden", and though attesting his Athenian citizenship makes it quite clear he was a Mithridatic export. ${ }^{28}$ The main strength of Pontus was now about to move overland into Macedonia, but Mithridates' only naval strength in the Aegean came from the pirate fleets he had sheltered from the Romans. An advance naval base of Athens' quality would be a nice thing to have, unbalancing the Roman supply-lines through Achaea, and interfering with the ability of a Roman fleet to harass his shoreward flank as he moved west. Even if it served only as a diversion he would not have lost much on the gamble.29

Thus, as Aristion flashed his "Epicurean" credentials in Athens and put the city on a siege footing, a small force of Pontic regulars under the command of

25. Athenaeus v, 215b. Ferguson, 446, n. 1.

26. Appian, Mithridatic Wars v, 28, 29. Athenaeus, v 212 (which Sherwin-White gives as Poseidonius, frag. 36J.50, according to the Kidd edtn.). Sherwin-White's analysis of these diplomatic aspects of Mithridates' strategy is quite good, though he far over-estimates the chances of the land campaign into central Greece (which cannot have been aimed at more than the creation of a buffer for the real Pontic gains in Asia). See Roman Foreign Policy in the East: 168 B.C. to A.D. 1, (London, 1984), $137 \mathrm{f}$.

27. On the question of Aristion vs. Athenion see Ferguson, 447, n. 1. Badian, "Rome, Athens, and Mithridates," 514, 515. Sherwin-White, op. cit.,. 135, n. 13. Though Appian confuses the two, the names are not textually similar, and the accounts elsewhere are distinct. Strabo ix, 398 recollects the tradition of more than one tyrant during this period. Plutarch (Sulla, 12, 13, 14.11) is only concerned with events after the arrival of his subject. Cf. also Eutropius v, 6. Orosius vi, 2. Pausanias I, xx, 5; and III, xxiii, 3.

28. Appian, Mithridatic Wars v, 28. All Appian does clearly is attach Aristion's "philosophic sympathies" to the Epicurean style; it is possible consequently that the Garden enjoyed a run of unusual social clout during his early regime. The charge against the Epicurean Zeno for arranging a rival's murder may belong to this year. (Athenaeus xiii, 611b. Diogenes Laertius $x, 3$.)

29. Cf. the analysis of Sherwin-White, Foreign Policy, 137. 
Archelaus appeared and began to dig itself into the Piraeus. ${ }^{30}$ No attempt was made to repair the Long Walls, or to use any additional of Mithridates' troops (no more, that is, than the guard that had arrived with Aristion) in defense of Athens itself.

Aristion instead placed the city under martial law, and attempted again to stem the flow of refugees toward the Roman centers of Greece, executing some and sending others captive to Pontus. ${ }^{31}$ Though it cannot have helped the image of his regime, he also allowed some Athenians with connections in Pontus to sail there for the duration of the emergency. ${ }^{32}$

\section{The Other Side of Catastrophe - The Western Contribution}

Now came the twist which gave a flavor of perverse legend to this story. The Roman commander first in Greece with an intent to do something about the Athenian crisis turned out to be Sulla, an official outlaw with a renegade army faced by resistance to an attempted coup behind his back in Italy, and anxious to effect a visible victory, preferably without crossing the Aegean, and then to return westward as quickly as possible. Sulla consequently moved directly on Athens and set siege to it, though his rather unsupplied force concentrated on the Piraeus and its docks. ${ }^{33}$ With the supporters of Marius now controlling Rome, he could not call on a fleet from Italy, and sent his lieutenant Lucullus to forage for ships in Egypt. $^{34}$

Archelaus and his regulars were able to prevent Sulla gaining any access to the port either rapid or inexpensive in blood. Sulla (fuming) encamped himself at Eleusis and began to wear Athens itself down by strangulation. What remained of the Long Walls he improvised into a ramp against the Piraeus walls, while by a series of around the upper city he actually aided Aristion in his effort to end the flow of refugees. ${ }^{35}$

Famine now began to tighten in Athens, and though neither Appian nor Plutarch mention mass starvation, they do speak of an unprecedented inflation in

\footnotetext{
30. Appian, Mithridatic Wars v, 28.

31. Idem.

32. Plutarch, Lucullus, 19.

33. Appian, Mithridatic Wars v, 30.

34. Appian, Mithridatic Wars v, 33.

35. Pausanias I, xx, 7. On the connection with Delphi during this crisis, see Ferguson, 449, n. 1 (which perhaps misses the point). Ferguson does not notice that the refugees who fled to Delphi seem to have been those most alarmed by the Mithridatic tyranny at Athens, and least antagonistic to Rome. The son of Medeius who appears later pleading for mercy during the Sullan sack was probably among their number. Sulla's sack of Delphi was not a punishment for collaboration but an "immediate gratification" of his financial and trophy needs for the coming campaign in Italy.
} 
grain prices. Gold "Mithridatic" siege coins, followed by heavy bronze issues struck in apparent extreme haste, remain from this year. ${ }^{36} \mathrm{~A}$ well in the Agora, closed after the end of the siege, was discovered upon excavation to be full of the remains of exposed infants and dogs ${ }^{37}$ Athenians ate the sedge that grew on the acropolis, and when that failed began to stew leather. Appian records Roman soldiers after the fall of Athens discovering homes where human flesh had been prepared for consumption. ${ }^{38}$

Plutarch records the price of grain running as high as 1,000 drachmas per medimnos, which Peter Garnsey finds incredible. Prices during the Hellenistic siege of Athens by Demetrius Poliorcetes ran at some twentieth of that level. ${ }^{39} \mathrm{He}$ may, however, have missed the point. Plutarch in the same passage ${ }^{40}$ is explaining that Aristion's primary difficulty lay in keeping up the appearance as long as possible that Athens was resolute in opposing Sulla, and would never surrender. In the midst of the city's dearth his loyal supporters (there were apparently very few of them) were rewarded with wild parties and tables well-supplied with food. Embassies from the Areopagus begging for a truce with Rome were driven away by his archers. The 1,000 drachma per medimnos price that so bothers Garnsey was very likely an attempt to suppress his opposition.

The key to understanding this is to keep firmly in mind that by this point Athens was, strange as it may sound, victim of two simultaneous "hostage crises," a dilemma not perhaps unique in ancient history, but one with many modern parallels. One faction held it by force to make a propagandist point; another besieged it to create a base from which to attempt conquests it considered, ultimately, far more important than what happened on the shores of the Aegean. Athenian heritage, the city's value as a symbol, made it a victim, and the suffering within the walls, real as well as that exaggerated for other eyes ("for the press" as we might say today) was pain spent to further goals unconnected with the city's own.

36. Appian, Mithridatic Wars v, 30-32, 34, 36-37, 40. Plutarch, Sulla, passes over the destruction of the Piraeus, and concentrates on the fate of Athens. Cf. Ferguson, 448, n. 3. Garland, 191, n. 56. Sherwin-White, Foreign Policy, 138, n. 22.

37. See J.L. Angel, "Skeletal Material from Attica," Hesperia, vol. 14 (1945), 279-363, and esp. inventory no. 116 on p. 311, Fig. 12 on p. 312. Plutarch, Sulla, 13. Appian, Mithridatic Wars v, 38. Cf. Peter Garnsey, Famine and Food Supply in the Greco-Roman World, (Cambridge, 1989), 36, n. 31.

38. Appian, Mithridatic Wars v, 38. Plutarch's Sulla makes no reference to cannibalism though he reports an exceedingly high price charged for grain. Frankness about such matters as cannibalism might not have fit comfortably with Plutarch's narrative style in any case. Cf. Garnsey, pp. 28, 29, n.16.

39. Plutarch, Sulla, 13. Cf. Cicero, Second Verrine, II, iii, 214; compare with II, iii, 84 and 90, 173-175, 189, 194, giving or stressing ordinary "panic prices" for (Sicilian) grain.

40. Plutarch, Sulla, 13. 


\begin{abstract}
Athenian Ashes
In the end, in the Athens of 88 B.C., Aristion failed in both his missions. Sulla, driven by his need to end the crisis and march on Italy (as well as by his own characteristic wildness when kept too long at any one challenge), improvised siege engines at last by gutting the trees out of the old grove of Academe where Socrates had once taught..$^{41}$ Athens' old rival Thebes was cajoled into providing catapults and scaling irons. In the end Sulla found a stretch of wall along the western circuit unguarded one night and rushed into Athens through the streets of the Kerameikos, allowing his troops indiscriminate slaughter until Plutarch says the gutters ran with blood. ${ }^{42}$ Pleas from Athenian refugees (including the son of Medeius), and from Roman Senators in his own entourage finally ended the killing. Aristion fled to the acropolis, burning the Odeion of Pericles as he went to make a last pseudo-Athenian "statement" of defiance, or to deny Sulla timber to use against his associates in the Piraeus, but he held out only a short time, and posed no realistic delaying threat. Sulla was free to depart and face the army of Pontus. Later Athenian legend noted that Athens fell in the month (Anthesterion) sacred to the memory of Deucalion's flood, to "ruin and destruction."
\end{abstract}

"On the same day and at the very hour when Curio brought [Aristion] down as a prisoner, clouds gathered in a clear sky, and so much rain fell that the acropolis was filled with water."43

The Piraeus fell shortly thereafter, when Archelaus (judging the strategic value of this southern "diversion" had run out) left to join the main Mithridatic forces entering Greece. Sulla moved to follow, but only after having burned the Piraeus thoroughly. He intended now to deal with Mithridates as quickly as he could; the cosmetic appearance of victory would suffice so long as he could negotiate an Aegean stable enough to last while he returned westward. He had not succeeded in scavenging a fleet for himself in Greece, and so did not need a naval base, nor did he intend to leave any opportunity for a fresh Pontic adventure in his absence. Of the famous shipyards, emporiae, and merchanthouses Sulla left standing only the temple of his favorite goddess.

About more lasting strategic needs in the Aegean Sulla showed his usual lack of long-term interest. Mithridates, not he, was the player of the "long game" in the chess of power. Mithridates would return.

Athens regained control of Delos as Sulla departed; it may have helped ease the loss of a devastated Piraeus, but its trade was never the same again, and after the re-founding of Corinth in the 40's went into irreparable decline. The

\footnotetext{
41. Appian, Mithridatic Wars v, 30.

42. Plutarch, Sulla, 14.

43. Ibid.
} 
government slowly appeared to return to its old form, but the Areopagus (now resembling a sort of Senate of 600) was charged with many matters the citizen ecclesia had once decided. ${ }^{44}$ The Herald of the Areopagus and the hoplite general (the shadow "consuls" or "praetors" of its new baldly Roman lease on life) became the chief authorities in the city. ${ }^{45}$

Athens had nothing left of the glory-dreams of a favored independence or leadership (through its schools, or because it would somehow be indispensable as an eastern business agent) that had grown up under the early favor of Rome. Taken without the symbols of its past, it was only the shell of a ruined city - a city which even the forced attentions of a cynical and ruthless Asian monarch could not enlist in the cause of "Greek freedom." Its survival lay in what it could make of the few shreds of local resource and Roman, or "European," favor it had left.

So, the double hostage crisis - Athens held at the mercy of Mithridates' agents to keep Rome from looking to closely at the east, Athens ruined at the mercy of Sulla so a politically opportunistic thug uninterested in the legacy of governance by dialogue (which Mithridates' agents had used) could attack and undo his own ailing republic in the west - destroyed the image Athens had had of itself since Pericles, however out of date it was, and left if really only one way to play its last card of value, the last real resource it had for survival.

The heart of this resource, as well as the underlying vulnerability which had involved it in the disaster just played out, lay in the Athenian decision to "be" a European city, to cast its future in the same direction it has today - to shift the focus of its dialogue about the 'humanities' (including governance) from internalist, from Hellenistic, to Mediterranean/European. To a Europe which had learned so much, already, often unwillingly, from Athens, the potential (if one can talk about such a concept as "cultural capital") was considerable; Roman Europe expressed its aspirations and justified its civilization in Greek, and particularly in "Athenian" terms. But a symbol always faces the danger of moments when it seems "just" a symbol; politicians in a wider EuroMediterranean world might, when they had more pressing concerns, leave it disastrously on its own.

In the age of Sulla and Mithridates, Athens survived in spite of this neglect, and in doing so added to its legend for later Romans like Cicero and Augustus. Again, in the last two hundred years Athens and modern Greece have done the same, but once more the result in our day has been for the Greeks a cultural dilemma, constant challenges of balancing heritage and influence with location. The ancient resilience in facing these seems unchanged.

44. Ferguson, 454-455. James H. Oliver, The Civic Tradition and Roman Athens, (Baltimore, 1983),. $57 \mathrm{f}$.

45. Strabo IX, xx, 398. Appian, Mithridatic Wars v, 39. Inscriptiones Graecae (vol. XII), 8.26. Cf. Ferguson, 455-457. 


\section{Bibliography}

Angel, J.L. "Skeletal Material from Attica." Hesperia, vol. 14 (1945): 279-363.

Badian, "Rome, Athens, and Mithridates." In American Journal of Ancient History, vol. 1 (1976).

Ferguson, W.S. Hellenistic Athens: an Historical Essay. London, 1911.

Ferrary, Jean-Louie. Philhellénisme et Impérialisme: Aspects Idéologiques de la Conquête Romaine du Monde Hellénistique, de la Seconde Guerre de Macédoine à la Guerre Contre Mithridate. Rome, 1988.

Garnsey, Peter. Famine and Food Supply in the Greco-Roman World. Cambridge, 1989.

MacKendrick, P. "The Athenian Aristocracy 399-31 B.C." Martin Lectures, vol. xiii (1969).

Oliver, James H. The Civic Tradition and Roman Athens. Baltimore, 1983.

Sherwin-White, A. N. Roman Foreign Policy in the East: 168 B.C. to A.D. 1. London, 1984.

Tracy, S.V. Inscriptiones Graecae II ${ }^{2}$ 2336: Contributors of First Fruits for the Pythaïs.

Meisenheim am Glan : A. Hain, 1982.

\section{Appendix - A Note on Methodology}

I have in general argued over the years that the business of the historian is the synthesis of the story from examined evidence, that intrusive emphasis on methodology is one of the flaws in, certainly not one of the gems of, contemporary historical writing. Too often it is an easy substitute for it.

It might be worth noting that this study of the hostage crisis of 88 began from a series of projects presented at ATINER in recent years on the evolution of the Athenian schools for survival in the Hellenistic-Roman market, the first of these published in The Athens Journal of History in 2017. ${ }^{46}$ This in particular came of a study - presented but yet to be published in this series, on the Peripatetic school, which late $19^{\text {th }}$ and late $20^{\text {th }}$ century European scholars credited as a first Athenian 'students in the streets' moment.

My point of examination for evidence was the scholarly identification of scholars and teachers in the changing schools, and their impact on the city of Athens as it changed, though the connection of scholars with Asian politics in this story paralleled a survival tactic in some of the schools I had noticed when curious simply about their academic changes. This tragic episode in Athenian history (certainly as devastating as the destruction of the city by Xerxes) has in recent generations been seen as tragic triumph of student protest, or nationalist revolt. I have offered some gathered strands of clues (in a short piece) to suggest a perspective in the evolution of the town makes more sense.

My hope in this very short piece is to shed light on the components of a narrative thread that makes more sense of the experience on the city itself.

46. Stoics and Epicureans for the 'Modern Market': How Athenian Educators ReTooled the Old City's 'Modernist Schools' for Republican Rome, The Athens Journal of History, (Vol 4, issue 4 October 2017). 